DOI: https://doi.org/10.31933/dijemss.v2i5

Received: 25 June 2021, Revised: 10 July 2021, Publish: 28 July 2021

\begin{tabular}{|c|c|c|}
\hline PINASTIP & $\begin{array}{l}\text { DIJEMSS } \\
\text { DINASTI INTERNATIONAL JOURNAL } \\
\text { OF EDUCATION MANAGEMENT AND } \\
\text { SOCIAL SCIENCE }\end{array}$ & $\begin{array}{r}\text { https://dinastipub.org/DIJEMSS } \\
\text { editor@dinastipub.org } \\
08117401455\end{array}$ \\
\hline
\end{tabular}

\title{
THE EFFECT OF LATE DELIVERY OF PARTS AGAINST SHIP OPERATIONS AT PT. SUMBERBUMI GLOBAL NIAGA
}

\author{
Vidya Selasdini ${ }^{1}$, Sursina Sursina ${ }^{2}$, Hasna Fariz ${ }^{3}$ \\ ${ }^{1)}$ Merchant Marine Higher Education, selasdini.vidya@ gmail.com \\ ${ }^{2)}$ Merchant Marine Higher Education, inateknika@gmail.com \\ ${ }^{3)}$ Merchant Marine Higher Education, hasna.fariz50@gmail.com
}

\section{Corresponding Author: Vidya Selasdini}

\begin{abstract}
Abstact: The sea transportation system plays a very important role in a country's economy. but there are still a number of issues that are of concern to commercial companies such as late delivery of spare parts and ship operations that occur at PT. Sumberbumi Global Niaga. Based on these problems the authors also conducted an analysis to determine whether there is an effect of the late delivery of spare parts to the ship's operations. The author uses quantitative research methods. With a total sample of 12 items. In searching for the calculation results the authors conducted several data analyzes with the results of the correlation test of 0.897 (rxy $=0.897)$ which proved that a positive correlation exists. And while tcount $=6,812(6,812>$ $1,812)$ and fcount $=17.14(17.14>4.96)$, where if tcount $>$ ttable and fcount $>$ ftabel Linear regression equation is $\mathrm{Y}=\mathrm{A}+\mathrm{bX}$, then there is a significant relationship between variable late delivery of spare parts against ship operations. Therefore, the results of the study showed that the late delivery of spare parts proved to be significant for ship operations at PT. Sumberbumi Global Niaga. The author also explained several solutions, namely by applying additional spare parts or backup. The goal is as an anticipation if there is a lack of supply of ship parts, so that ship operations are not disrupted if there is a lead time on spare parts.
\end{abstract}

Keywords: Delivery of Parts, Procurement of Parts, Ship Operations

\section{INTRODUCTION}

The sea transportation system is currently experiencing progress, therefore shipping companies experience an important role as a company that provides sea transportation services both for transporting people (passengers), goods (cargo), animals and plants. The role of shipping companies also influences the process of the country's economic activities. The need for shipping fleets is proof that opportunities have been opened to develop the shipping business. 
To fulfill the contract in an agreed agreement required good ship operations. Good ship operations are determined by good ship performance. A good ship performance must be supported by the procurement of appropriate and timely spare parts in its supply. Vessel operational activities are the implementation of planned ship activities during operation. The operation of ships requires a high cost so that the speed and timeliness, especially at the port for the purpose of loading and unloading is absolutely necessary, because if there is a delay it will have an impact on high port costs. Delay in loading and unloading activities can be caused by ship engines or supporting equipment for loading and unloading on ships often experiencing damage during loading and unloading operational activities. So the procurement of spare parts and ship repairs need to be continuously improved so that the smooth operation of the ship's operations is guaranteed. The smooth operation of the ship certainly cannot be separated from the spare parts as well as good coordination between the company and the supplier and crew.

In its operation, PT. SumberBumi Global Niaga has not been optimal because of spare parts experiencing excessive waiting times where the procurement takes a long time, due to lack of coordination between suppliers with the ship and logistics, ordered goods are not available at suppliers, they have to find other suppliers, and goods that are Required cannot be postponed if the delay will disrupt the operation of the ship. This caused a delay in the operation of the ship because the ship had to make repairs and wait for spare parts to come on board, and the ship's departure was delayed. Operations can run optimally if supported by timely delivery and supply of spare parts,

The objectives of this study are:

To find out, analyze and measure the effect of the late delivery of spare parts on ship operations on PT. SumberBumi Global Niaga

The benefits of this research are:

a. Theoretical aspects

The scientific benefits obtained from this research are to help the company to optimize the time in sending spare parts as a feedback from the company so that the operational targets of the ship can be met so that it can meet the needs of the ship set by the company.

b. Practical aspects

As a final project and scientific work in the form of a thesis that must be done by the author. And this research is useful as information and consideration for companies, service users and educational institutions in overcoming and analyzing and understanding the effect of late delivery of spare parts on ship operations.

\section{LITERATURE REVIEW \\ Definition of Ship Parts}

According to Richardus Eko Indrajit Richardus Djokopranoto (2005: 5) in his book Inventory Management states the definition of spare parts is as follows, "Spare parts or spare parts are a tool that supports the procurement of goods for the purposes of equipment used in the production process".

According to Lasse, DA (2012: 123), in his book "equipment management operational and maintenance aspects" the supply of spare parts is the need for spare parts that are known when the plan is determined with the information needs, the time of the procurement process of the parts is quite long, not in a hurry like when an emergency work occurs. Timely 
procurement, quantity and quality.

\section{Definition of ship Operations}

According to Hanjoyo Bono Nimpuno in the big Indonesian dictionary (2014: 44) operations are operations that are based on rules. While the operation is the implementation of a plan that has been developed. So the operation of the ship is the implementation of the planned activities of the ship during operation.

\section{METHODOLOGY}

The author determines the time of research at the time the authors carry out Land Practices in Shipping Companies PT. SumberBumi Global Niaga, starting from August 1, 2018 to August 9, 2019. This technique is used by the author to support the data and information that the author presents in order to complete the writing of the thesis, namely with how to view documents, and everything related to the problem that will be examined by the author owned by PT. SumberBumi Global Niaga which has been saved as a document.

Literature study is the collection of data by reading, viewing, researching, quoting from books or references presented, input or consideration and comparison of what can be seen from existing theories. This literature study aims to obtain the basics of theory with the problem to be discussed.

\section{Methode Data Collection Approaches and Techniques Approach Method}

In this thesis research this writing uses a quantitative data approach method. Data is information that is used in research, in order to provide an overview of the object under study, so that the problem under study can be discussed. In this study the data obtained and analyzed in the form of secondary data

\section{Data collection technique}

Some ways of data collection techniques are:

\section{Observation}

In this technique, the authors use research with directly by visiting the place under study. In this observation researchers looked directly and observed work activities in the operational, procurement, or other divisions at PT SumberBumi Global Niaga. the aim is to determine the effect of the delay in the time of spare parts procurement on the ship's operation

\section{Population}

The population consists of a group of objects that are the center of attention, from which contained information that you want to know (Gulo, 2002: 76) In this case, the population taken by the author in the preparation of this thesis is the data of all parts delivery, operational division performance, namely operational calculations ships in the form of on hire and off hire for the last twelve months at PT. Sumberbumi Global Niaga and calculated in the period of monthly in the period August 2018 to July 2019 in the company PT. Sumberbumi Global Niaga.

\section{Sample}

The sample is a subset of a population, the sample provides a true picture of the population. Taking a sample from a population is called sampling. The population that is 
sampled when planning a study is called the target population, while the population under study when conducting a study is called the sampling population. (Gulo, 2002: 78). The author uses a sample that is the report on the delivery of ship parts delays every month in one period.

\section{RESULT AND DISCUSSION}

After analyzing the data that has been done it can be seen the advantages and disadvantages of each indicator contained in the variable. From the analysis of these data it can also be seen what things are contained in the late delivery of spare parts (variable $\mathrm{X}$ ) which must be corrected to improve the operation of the ship (variable Y). Problem solving is a solution that can be used to solve problems from problem formulation. The following problem solving is taken based on the data obtained, which is based on the results of calculations that have been obtained, it has been proven that ship parts have a positive and significant relationship to ship operations with correlation coefficient data of $0.897(\mathrm{r}=0.897)$ which means it has a strong relationship, the validity test is valid because $0.897>0,5760$ (count $>r$ table). Then obtained $\mathrm{R} 2=0.79$, proving that this linear regression is feasible and the coefficient of determination of $79 \%$ ( $\mathrm{KD}=79 \%$ states that the late delivery of spare parts affects the operation of the ship then in $t=6,812(6,812>1,812)$, andfcount $=(17.14>4.96)$, where if $\mathrm{t}>\mathrm{t}$ table and fcount $>$ ftabelthen there is a significant relationship between variables $\mathrm{X}$ and $\mathrm{Y}$.

On the influence of the late delivery of ship parts on ship operations at PT. Sumberbumi Global Niaga, obtained a correlation coefficient of (0.897). This means that there is a strong influence between the late delivery of ship spare parts to ship operations. If the results of the correlation are positive, it can also be interpreted that if the late delivery of spare parts decreases, it will also decrease off-hire on ship operations. Vice versa. If there is an increase in the late delivery of ship parts, it will increase the potential of off-hire and disrupt ship operations. The following problem solving can be done to reduce the time delay in sending spare parts to the ship, namely as follows:

1. Optimizing the process of procuring parts

Ordering spare parts usually requires a waiting time due to the manufacturing process, in contrast to store items / materials which are easily obtained and processed. To overcome this, the company must order spare parts long before the spare parts are used so that the supply of goods needed by the ship is no delay and can be on time as specified. And also the company anticipates by implementing additional or spare parts. The goal is as an anticipation of the lack of supply of ship parts, so that it can guarantee the smooth operation of the ship. Besides being able to deal with delays in the delivery of spare parts,

2. Optimizing the performance of the technical manager so that in analyzing the needs of spare parts that have been shipped by the ship previously made an order to be effective. Therefore accuracy, speed in the analysis of technical managers is a major component in the procurement of spare parts to be on time.

3. Optimizing the main tasks of the procurement division in the procurement of spare parts for needs on the ship. This division should carry out the work responsibly and thoroughly if there is a request that has been sent by the ship. This needs to be done because of frequent delays in delivery.

4. Supplier is a party that has a very important role in the supply of spare parts, so that ordering of spare parts runs properly and smoothly without having to experience obstacles or disruptions ranging from price requests, orders, delivery of spare parts to the payment process. maintaining good relations with the supplier is very important in order to get a 
choice of relative and competitive prices, but by prioritizing quality or as an alternative way if spare parts are not available or not yet available at other suppliers.

5. Carrying out maintenance on the ship with accuracy in the procurement of ship parts with a complete inventory of maintenance can also be arranged. Maximize the use of old parts until they expire. Maintenance is one of the most important factors to be able to adjust to the absence of damage on board. Following are efforts to optimize ship engine maintenance:

Implement the engine maintenance strategy well. The engine maintenance strategy, namely:

1. Incidental Care for Planning Care. The first choice for determining a treatment strategy is between "incidental care" and "planned treatment". Incidental care means leaving the engine working until it is damaged. If we want to avoid the ship or suddenly stop in the middle of the journey with this strategy, then we must provide more capacity to accommodate the capacity of critical functions, very expensive, then some types of systems are expected to minimize damage and workload.In general, this mode of operation is very expensive, therefore some form of planning system is implemented by using a planned maintenance system, so our goal is to minimize damage and workload from a required maintenance work.

2. Preventive care for repair care. This preventive maintenance tries to prevent damage or to find damage to the ship's engine so that it can work optimally. The objectives of implementing this treatment system are:

1) to obtain regular ship operations and maintain their use;

2) to maintain the flexibility of the ship's engine so that operations can be used with different operators; and

3) to ensure continuity of maintenance work.

This is done by monitoring the condition of the ship's engine by checking the engine condition and other conditions, especially periodically. The intention is to provide adequate security for the deterioration of the normal condition of the ship's engine.

Preventive maintenance usually occurs from periodic opening of machinery and equipment to determine whether adjustments and replacements are needed. Such time periods are usually based on machine hours or calendar time. Storage and Management Machining parts have thousands of items and each item has a high price / value. But It is not always used all the time depending on the program of maintenance and repair of engines on the ship. Therefore, these parts are made safe, clean, organized, controlled storage in accordance with the name of the item, registered neatly for inspection and locked securely.

The following problem solving can be done to improve the operation of the ship so that there is no potential off-hire, namely as follows:

1) Providing training to the crew on proper engine maintenance. The crew must be given training before or while on board so they can operate the ship well. The crew of the ship who has extensive and experienced knowledge about engine maintenance will be easy to handle if there is a sudden obstacle then the engine damage can be dealt with quickly and precisely and the operation is not disrupted.

2) Increased capability and skills of operational divisions in which the output results are operational activities of ships that can or may not operate. Namely by providing training for 3 months at the beginning of the year into the company or better known as familirization. 
The factors that determine the estimation of the goods or parts until the ship is as follows:

1) High number of requests

2) The high cost of purchasing

3) The level of difficulty of the item to be found

4) Goods need to be made in advance so that they wait until the goods or spare parts needed are ready.

\section{CONCLUSIONS}

Based on the results of research and discussion of regression analysis and correlation coefficients, coefficient of determination, validity test, and hypothesis testing between the late delivery of ship parts to ship operations of PT. Sumberbumi Global Niaga obtained the following conclusions. It is proven that there is a very significant relationship between the late delivery of spare parts to ship operations. Which occurs the delay in spare parts is caused by lack of optimal parts procurement process and also the lack of maintenance performed. Because the accuracy in the procurement of spare parts is a major factor in order to reduce delays in the delivery of spare parts. If the delay in sending spare parts decreases, off hire will also decrease. Problem solving that can be done to reduce the level of off hire in ship operations is by conducting maintenance strategies because maintenance is one of the most important factors to be able to adjust so that there is no damage on the ship. Made to reduce delays in the delivery of spare parts and reduce the level of off-hire in ship operations, the authors advise interested parties in order to get positive input that is constructive for the sake of continuity in the management and progress of the company in the future.

\section{REFERENCES}

Abbas Salim. 2006. Manajemen Transportasi. Jakarta: Raja Grafindo.

Ariesta, Tika Pratama dan Mukti Wibowo. 2014. Plan Maintenance System untuk Safety Equipment di Kapal Volume 1, No. 1 yang dapat diakses melalui https://docplayer.info/47620331-Plan- maintenance-system-untuk-safety-equipmentdi- kapal.html (diakses Hasna Fariz pada 14 Januari 2020 pukul 15.13 WIB).

Assauri, Sofjan. 2008. Manajemen Produksi dan Operasi. Jakarta : Lembaga Penerbit Fakultas Ekonomi Universitas Indonesia.

Capt. R. P. Suyono, M.Mar, 2001. Shipping Pengangkutan Intermodal Ekspor Impor Melalui Laut Edisi IV, Jakarta.

Danuasmoro, Goenawan. 2003. Manajemen Perawatan.

Jakarta, penerbit: Yayasan Bina Citra Samudera.

Echols, John M. dan Hassan Shadily. 2014. Kamus Bahasa Inggris Indonesia. Jakarta : PT. Gramedia Pustaka Utama.

Gopalakrishnan, P., dan Banerji, A.K., 1997, Maintenance and Spare Parts Management, 1st ed., Rajkamal Electric Press, Delhi.

Indrajit, Richardus Eko., \& Djokopranoto, Richardus.

2015. Manajemen Persediaan. Jakarta: Gramedia Widiasarana Indonesia.

Kosasih dan Soewedo. 2007. Manajemen Perusahaan Pelayaran. Jakarta: PT. Rajagrafindo Persada.

Lasse, D. 2012. Manajemen peralatan : aspek operasional dan perawatan. Jakarta: PT Raja Grafindo Persada.

Sugiyono. 2004. Metode Penelitian Kuantitatif, Kualitatif dan R\&D. Bandung: Alfabeta.CV Sugiyono. 2017. Metode Penelitian Kuantitatif, Kualitatif dan R\&D. Bandung: Alfabeta.CV 
SOLAS Convention (Safety of Life at Sea) 1974/1978 as amended. ISM Code (International Safety Management Code) 1992/1996. 
PMS (Plan Maintenance System) dalam ISM Code 1992/1996.

Pemerintah Republik Indonesia. (2008). "Undang- Undang Republik Indonesia Nomor 17 Tahun 2008 Tentang Pelayaran”, Jakarta. 